\title{
Legal Standing of Coastal Reclamation: Islamic and Positive Law Perspectives
}

\author{
Supriadi \\ Faculty of Law Tadulako University \\ Jl. Soekarno-Hatta KM. 9, Palu, Central Sulawesi 94117, Indonesia. \\ Tel./Fax:+62-451-422611E-mail: talrev@untad.ac.id \\ Submitted: May 26, 2016; Reviewed: Jul 8, 2016; Accepted: Jul 28, 2016
}

\begin{abstract}
In several regions, the implementation of reclamation in Indonesia caused much conflict. At least, it caused by three interests; the interest of the government, employers, and society (fishermen). The interests of the Government and local authorities to give permission to reclaiming for the pursuit of local revenue, the interests of employers to reclaiming the coastal, because they wanted to add company's revenues, while the interests of society (fishermen) to defend coastal areas so it not diminish their livelihood. Reclamation in Indonesia has been governed by legislation, but it has not been able to resolve the coastal reclamation. This is due to the legislation governing coastal reclamation, and local governments are ignorant of the rules concerned. In addition, the central and local governments are often tends to interest of employers rather than the fishing communities, so it triggering conflict in reclamation. Positive law as a law made by the government and legislative assembly and the local government with local legislative, a rule that was born as result of an agreement between them, and neglecting the Islamic law that was created by God to organize all the things in this world, including in the management of the universe (coastal). God as the creator of this universe, allowing to manage and utilize natural, if for the benefit of humanity as a whole, and not for those of a human. Therefore, in the implementation of reclamation, the Government and local authorities need to synergize Islamic law into positive law in resolving the problems of social and natural resources.
\end{abstract}

Keywords: Reclamation; Islamic Law; Environmental Law; Positive Law

DOI: http://dx.doi.org/10.20956/halrev.v1n2.312

\section{INTRODUCTION}

Earth and everything in it is the Great Creator's creation universe, God Almighty. The omnipotence over all His creation, Allah has stretched the earth and everything in it, the earth has been inhabited by approximately 7 billion people today. Seventh billion more humans have been relying on the earth and all its contents. One of the content that has been given by Him is the ocean, and it has beach area that called "coastal areas".

The existence of the earth and the universe, basically Allah SWT creating for His creatures and as a place for living, earning a living is lawful. Earth and the universe, Allah SWT has filled with an abundance of natural resources in it. Today, earth comprising of ocean $2 / 3$ and land $1 / 3$, and the land has 
been filled overcrowded by approximately 7 billion of humans. Sea area that given by Allah SWT, became the target of humans to be used not only for business purposes in the field of fisheries, but a place to build economic interests, such as the development of island to become a new place.

Indonesia and many areas have a crowd to do reclamation of coastal with the reason that to add a new settlement and this trend imitate few countries in the world that has done so. The question arises whether Indonesia and some areas have been very need it, or because their purposes veiled initiated by entrepreneurs in the field of residential property developers. In Indonesia, regions that have done reclamation are ${ }^{1}$ (i) Makassar, South Sulawesi, Jakarta, Bali and Manado, North Sulawesi, and Palu, Central Sulawesi is being made stockpiling material.

In addition to Indonesia several countries that have been reclaimed, namely2: (i) Dubai; Palm Jumeirah ${ }^{3}$ (ii) Singapore; ${ }^{4}$ San-

1 The term of "reclamation" is derived from the English from the verb "reclaim" which means take it back, with emphasis on the word "back". In term of development, the term of reclaim is also used in example reclaim materials from the former buildings or debris, such as rocks, and gravel from the road construction, or gravel from the debris of concrete to be used again. In civil engineering or land engineering, a term of reclaim is also used in order to cultivate a piece of land that is not useful or less useful becomes useful again or more useful. How far, this degree of usefulness depends upon the goals to be achieved. In the development of residential and urban areas are sometimes puddles dried for later exploited, even the sea area can be used as the mainland, see: Abdoel Raoef Soehoed. (2004). Reklamasi Laut Dangkal, Canal Estate Pantai Mutiara Pluit, Perekayasaan dan Pelaksanaan Reklamasi bagi Proyek Pantai Mutiara di Pluit Jakarta. Jakarta: Djambatan, p. 4.

2 Source: id.m.wikipedia.org/wiki/Reklamasi_daratan, accessed on 5 May 2016.

3 Artificial island in shape Mini Pale Tree an area of $572.1 \mathrm{Ha}$. Land separated from the coastal, with a beautiful form

4 Sentoso island formerly known as Blakang Mati Island which later merged with the surrounding small islands. Sentoso Island an area of $500 \mathrm{Ha}$ has become a tourist toso Island; (iii) Hongkong; 5 implemented on a remote island; (iv) Netherlands: Port Rotterdam. ${ }^{6}$ The reclamation that conducted by some regions, however, thought is only based on materialism that developed in the western world who judges everything as material or money. Additionally, the reclamation is a denial of the values that are given by God Almighty into the hearts of human beings to provide guidance in this life. The denial of conscience is a trigger of the destruction of the environment, including marine and coastal areas. According to Isac Asinov and Frederik Pohl, as quoted by Abu Fatah Al-Adnan ${ }^{7}$ said that:

"Most humans are difficult to realize the reality of environmental destruction in the surrounding areas. This is due to the destruction of the environment coincided with the processes they're working on their own, which often aims to build the future. In fact, the opposite is true. The tragedy of the future, it is working in front of us and of our own work".

Referring to the views expressed by Isac Asinov and Frederik Pohl above, provide a view depicting humans in doing the job, not knowing effort done and the consequences that will result from the activities. On the other hand, God create mind that there is in

center that offers a variety of entertainment facilities, hotels, parks, villas etc.

5 Tung Chung Island is formerly as remote islands covering an area of $14 \mathrm{Ha}$, now the main magnet of Tung Chung is Hong Kong's international airport and shopping.

6 Port Rotterdam is a successful reclamation in the world. Harbor as a result of reclamation by Maaksvlakte 1 project has reached maximum capacity, then Maaskvlakte 2 project which generates a new port that has been empowered for commercial purposes since 2013. Port Rotterdam became the largest port in continental Europe with throughput figures per year is 465 million tons.

7 Mukhtasor. (2007). Pencemaran Pesisir dan Laut. Jakarta: PT. Pradnya Paramita, p. 2 
mans' head to serve as a differentiator right and wrong, right and vanity, that damage others and benefit for themselves. Why is that, because humans are free to exclude the idea, without thinking of accountability for what they do that before God someday.

The development of coastal reclamation, to other human beings is a potential to be developed to obtain material gain, but what human realize that millions or even hundreds of thousands of other God's creatures, which has the same right to enjoy the nature. The consideration are not concerned with the interests of others that God's creatures, so that people believe that the earth created by God just pointless, because it does not have meaning for other creatures. God created the universe with perfect circumstances, and each character. The provisions in the Qur'an, QS Al-Qamar, verse 59), Allah Almighty says: "Everything (in this universe) I created all-sized".

Meaning contained in Q.S. Al-Qamar, 54:49 above, become a deep contemplation that God created the universe with all its contents, such as mountains, sea, river, plants, humans and animals have been measured both with and without disabilities, but humans that give label that universe and all other creature have disadvantages. The coastal has been created by God with an appropriate, conducted by reclamation with a reason to improve the welfare of human beings and disregard to others, is a denial of God himself. Humans and the Government and local governments forget that the world and its contents belong to Him.

As several provisions in the Holy Book of the Qur'an that have been discussed about the existence of the universe, in substance not discuss specifically regarding beaches or coastal, however, the duty of man to explore with His command, as guidelines for humans to manage this universe. Therefore, worldly man makes positive law as special norms governing the coastal areas and set about reclaiming it. The reclamation, normatively regulated in Article 34 of Act No. 27 of 2007 on the Management of Coastal Areas stated that:

(1) The reclamation of coastal areas and small Islands is conducted in order to increase the benefits and/or value added of Coastal Areas and Small Islands in terms of technical, environmental, social and economic aspects;

(2) The reclamation as referred to in paragraph (1) obligate to keeping and attention to: a. sustainability of life and livelihood; b. balance between the interests of utilization and for conservation of Coastal and Small Islands; and c. technical requirements for extraction, dredging and stockpile material; and

(3) The planning and reclamation further regulated by Presidential Decree.

Referring to the provisions set forth in Article 34 of Act No. 27 of 2007 above, illustrates that the implementation of reclamation is allowed to meet the provisions: First, increase the added value of Coastal Areas and Small Islands; Second, meet 3 (three) technical requirements, environmental and socio-economic technical; Third, required to maintain the sustainability of the lives and livelihood of the people, balance between utilization and conservation of coastal area 
and small Island, extraction, dredging and stockpile material; and fourth, the planning and implementation of reclamation regulated by Presidential Decree. The fourth point which is the main concern for reclamation, for all four of these requirements can be studied from the perspective of Islam- and positive laws in Indonesia.

\section{METHOD}

This research was conducted by using normative research. ${ }^{8}$ In this normative research is essentially seeking the validity of coherence, is a validity based on correspondence between studied with the rules set. This study used two approaches, namely: (i) concept approach; and (ii) Statute approach; and (iii) comparative approach. Concept approach is expected to find an idea to produce a concept and legal arguments relating to the implementation of reclamation. Statute approach is to analyze whole legislation related to the coastal reclamation. While, the comparative approach is to compares the views of Islam and positive laws in view of the implementation of reclamation in Indonesia. This study began with a study of positive law, including Islamic law, which now becomes a positive law in Indonesia. Therefore, it still ended into three layers of law, namely: legal philosophy, legal theory, and legal dogmatic. In addition, this study also will systematize in both primary and secondary law. ${ }^{9}$

\footnotetext{
Peter Machmud Marzuki. (2011). Penelitian Hukum. Jakarta: Pranada Media Group, p. 3

9 Primary legal materials are authorative law materials has authority. It is consisting of: The 1945 Constitution of the Republic of Indonesia (Act, government regulations, Presidential Decree, etc.), official records or circular in the making of legislation and the judge's decision. Secondary law material, all the scientific publications on the law, which is not an official documents, publications about the law, including textbooks, law
}

\section{ANALYSIS AND DISCUSSION}

A View of Islamic Law on the Implementation of Coastal Reclamation

Islamic religion has the Holy Book “Qur'an", in it governs all God's commands and prohibitions as well as setting the entire universe. Therefore, the discussion on the reclamation, in this study carried out by the arguments put forward in the Qur'an in general. Therefore, talking about the beach/coastal is an integral part of the universe, and reclamation activities is a natural phenomenon related to the human activity.

Beach, coastal and marine areas is a place of other God's creature to shelter and feeding sites, human should not damage the community where other creatures. Main factor that causing damage to the beach and the sea, because the activity of human to change it (reclamation). Damage to the universe, including the sea and the beach by Allah has warned in Q.S. Ar-Rum, 30:

"Have it appears the damage on land and sea because of what the hands of men, that God may feeling them some of (due to) their actions, so they come back (to the right street)."

Referring to the words of Allah above, depicts the God's statement regarding the damage on land and at sea, as a result of human actions only concerned with self interest of the man himself and his group. Humans who do the destruction of the environment, in particular the reclamation is a human activity that reflects the moral quality is very low. H.M. Talhah and Achmad Mufid ${ }^{10}$ said that the moral values of society in which we

dictionaries, legal journals and commentaries on court rulings, see Peter Machmud, Ibid.

10 H.M. Talhah and Achmad Mufid. (2008). Fiqih Ekologi, Menjaga Bumi Memahami Makna Kitab Suci. Yogyakarta: Total Media, p. 229 
live have been misleading. These moral principles that are the result of the selfish and the rasp of society, then turned into egoistic, arrogance, cynicism, violence, and brutality in society. People believe that to improve the standard of living, they have to cheat and defeat others.

Development activities or the reclamation of coastal, in the view of human today is still leave behind pros and cons. Man wanted that the development or the reclamation for the public welfare, increase local revenue. But on the other hand, the reclamation activities make people become homeless, lost livelihoods, killing hundreds of millions of creatures that live and reside on the beach in question. The view that, the activities of coastal reclamation bring benefits, that's the picture of human and the low of moral values and arrogance. In modern times, revealing man who has been away from their closeness to God, since modern humans today are more concerned with the ability to think and away from the award of himself as a noble creature in comparison to the other God's creatures. Abu Fatiah Al-Adnani ${ }^{11}$ said that:

"So, it is no excessive to say that these last days are a meeting point between the nature laws and human character. Sunnatullah (nature law) means that the whole journey of human life and the universe is going to follow the "destiny" and in accordance with the plan that God has set, which in this case has God let the long journey to Rasulullah SAW. The character of human being means that it is the tendency of man to follow his own

\footnotetext{
11 Abu Fatah Al-Adnani. (2008). Global Warming, Sebuah Isyarat Dekatnya Akhir Zaman dan Kehancuran Dunia. Surakarta: Granada Mediatama, p. 20
}

lusts, which would have ended with the destruction."

Referring to the view of Abu Fatiah Al-Adnani above, indicates that humans in this century have forgotten the nature laws (Sunnatullah), because humans is more pursuing the world and the hereafter. The forgetfulness against the nature laws, because people take the ability to do something by relying on his brain, so it will do what they to think, and feel the results if the mind has reached a value of truth. An example of reclamation in some areas, especially in Jakarta, local governments' mind with reclaiming and making 17 islands in the bay of Jakarta, will add a new shelter, resulting revenue for Jakarta area. But on the other hand, the impact is displacing populations residing in North Jakarta and move into bunk house (flats) that far from seeking livelihood, the question is whether this act is damaging or not, and this invites further debate the pros and cons.

People who support this reclamation, for having had the benefit of the developer, while the public counter, consider that, evictions conducted by the Jakarta administration has damaged the joints of their livelihood. Following the views of pro, this is the picture of human to simplify mind and saying that, the earth and all the natural resources are intended for humans on earth as human as caliph.

In the perspective of Islamic law, which includes the beach or coastal areas equal its position with human? According to Seyyed Hossewi Nasr ${ }^{12}$ that the Qur'an defines the

\footnotetext{
12 Fachruddin Mangunjaya et al., (2007). Menanam Sebelum Kiamat, Islam, Ekolgi, dan Gerakan Lingkungan Hidup. ICAS. Jakarta: Yayasan Obor Indonesia. p. 55
} 
universe regards as the presence of humans, and nature is part of the revelations in the Qur'an. The universe itself is the first revelation of God, which is in it the leaves of the trees, the mountains, all kinds of animals, just as also the wind and the gentle flow of water, is a sign of God. All of these are the messages contained in the first revelation. That is why the classical Islamic teaching says referring to the Qur'an (al-Qur'an altakwini) and Qur'an cosmic (al-Qur'an alTadwini). Other verse of Qur'an mention the phenomena in the nature and events in the human soul are all referring to cues or signs (verses) of God in the Qur'an itself.

As modern human has forgotten his existence as servant, and felt that modern humans are independent humans and free to do whatever they think. When the human mind is what makes humans enter into the abyss, which will not be able to out of the abyss, when mankind has realized himself that they are servants of God on earth. Conducting activities to change the landscape, for the modern human is a very successful activity with the help of its technology, but human beings forget that, as caliph, the God permits to do activities to the earth or nature, but it must comply with the laws that God wants, not laws made by humans. Therefore, to restore human beings to nature, only one way to bring men back to spiritualism on him and hold the teachings of their respective religions.

\section{The Implementation of Coastal Reclama- tion from Positive Law Perspective}

Management and utilization of coastal areas for the sake of development constitutional- ly regulated in Article 33 paragraph (3) the Constitution 1945. The existence of Article 33 paragraph (3) becomes the fulcrum in managing all natural resources, whether on land, in the water, the ocean and in coastal areas. The Constitution of the Republic of Indonesia 1945 is the highest law to all legislation and regulations underneath, and became a main reference in the legislation underneath. In addition, the Constitution of the Republic of Indonesia has recognized that, Indonesia is an archipelago country, this according to the provisions of Article 25A of the 1945 Constitution of the Republic of Indonesia stated that:

The Unitary State of the Republic of Indonesia shall be a state with many islands characterized by Nusantara (Archipelago) of which the borders and rights shall be stipulated by virtue of law.

Referring to the provisions of Article 25A and Article 33 paragraph (3) The 1945 Constitution of the Republic of Indonesia above, the Government made legislation governing the management of Coastal Areas and Small Islands and the coast, namely: (i) Act No. 12014 on the amendment of Act No. 27 of 2007 concerning Coastal Areas and Small Islands; (ii) Act No. 23 of 2014 concerning Regional Government; (iii) Act No. 32 of 2009 concerning the Protection and Environmental Management. For details will be described below:

Act No. 27 of 2007 concerning Coastal Areas and Small Islands

The existence of Act No. 27 of 2007 concerning the Management of Coastal Areas and Small Islands, is one of the 
organic regulations of Article 33 paragraph (3) the 1945 Constitution. The coastal area is one of the natural wealth that is included in the state's control, because its existence used as much as possible for the benefit of people, especially for people in its surrounding and fishing communities. Dictum weigh particularly points $a$ stated that:

Coastal areas and small Islands are part of the natural resources bestowed by the God Almighty and the wealth controlled by the state, which needs to be preserved and utilized for the welfare of the people, both the present generation and the generations to come.

A very important meaning conveyed in dictum letter $a$, has explained that the management of coastal areas and small islands in it can be drawn the conclusion: (i) a part of the natural resources; (ii) the grace of God Almighty; (iii) the wealth controlled by the state; (iv) need to be preserved; (v) exploited in the prosperity of the people; and (vi) for the current generation and for generations to come.

Referring to the conclusions drawn from the dictum weigh letter $a$ above, has been very clear about the nature of management of coastal areas and small islands, its ending point is the grace of God Almighty. This grace sentence has a very deep meaning, because it concerns the dimensions of the divinity, and this dimension as marker recognition of the Indonesian people against natural resources, especially coastal areas and small islands are His. Thus, the recognition that natural resources is a gift of God, then its consequence is Indonesia nation should not be tinkering with natural resources, including beaches or coastal.
Beach as an integral part of the coastal area has economic value is very big as a man who has a lot of funds, because the beach is an asset that can be developed to build their business purposes. Recognition in economic terms, it has been described in the dictum weighing the letter $b$ of Act No. 27 of 2007 states that: "Coastal Areas and Small Islands has a variety of natural resource potential is high, and very important for the development of social, economic, cultural, environmental and buffer sovereignty of the nation, therefore, need to be managed in a sustainable and global perspective, taking into account the aspirations and participation, and values of the nation based on national norms".

Referring to the provisions of dictum weigh letter $b$ of Act No. 27 of 2007 above, a portrait of the potential contained in coastal areas and small islands, including coastal areas which in reality has a value that diverse. The provisions in Article 3 of Act No. 27 of 2007 states that: management of coastal areas and small islands based on: a) Sustainability; b) Consistency; c) Alignment; d) Legal Certainty; e) Partnerships; f) Equalization; g) Community Participation; h) Openness; i). Decentralization; j) Accountability; and k) Justice.

Focused on the provision of Article 3 of Act No. 27 of 2007 above, had provided information on the principles used as a basis in the implementation of coastal area management, particularly the reclamation. The implementation of the principles contained in Act No. 27 of 2007 , meaning that the management of coastal areas, especially the beach for reclamation, the principles are the main reference, because the reality 
shows that the incidence of conflicts in a problem, due to neglect where principles are concerned.

In plain, which happens to reclamation undertaken by the Government and local government, the primary consideration is only for economic aspect, the aspects of environmental and socio-cultural into consideration so many, and economic considerations this is a major consideration, since this aspect are benefit financially. The main consideration of economic aspect, is relate to the human ability to see the universe, including the coastal areas or the beach as an object that has a very high value, and has ignored other aspects. By Emil Salim ${ }^{13}$ said that development actually touching various aspects of the human dimension. Human beings are not "economic animal" who merely lives pursuing "more" rather than "less" greedy "eat" their rival. Humans actually have a variety of "face" reflects the complexity of human beings.

As view of Emil Salim above, placing the position of human as central in conducting development, but that it is unfortunate that humans today have become savage and greedy as standard measure used to achieve success is the term of economy. One that looked on the eyelids is the presence of reclamation in several regions in Indonesia, be a very interesting issue because by reclaiming the beach, so people who have big capital, consider the beach and the sea is a very lucrative business opportunity. With the economy the dominant factor, then the business people already forget your human

13 Emil Salim. (2010). Ratusan Bangsa Merusak Satu Bumi. Jakarta: Kompas Penerbit Buku, p. xxv dignity and prestige, because in his mind how to expand business with a thousand ways and face. Economic factor is the cause and appeared shift in values of public and previously as Paguyuban changes into Patambayan, a community just above selfish interests and their group.

Referring to the view of Emil Salim above, become a basis associated with the understanding of spiritual values in a person, because when humans have lost the spiritual values in him, then there is the bestiality that has permeated into the heart. Given the nature of brutality in modern human today, the human concerned shall make natural resources as the target object that is free, because these resources have been provided by God. On the other hand, the man in question only requires the recognition in the form of a license issued by the competent authority, and with the base that is the handle to make the exploitation of natural resources, including coastal areas or the beach.

\section{Act No. 26 of 2007 concerning Spatial Planning}

Spatial is an integral part of the whole universe and its contents which have a function to live for human beings to perform their activities. It is one of the natural wealth that is controlled by the state in the framework of the welfare of its citizens, and its utilization should still refer to the provisions of Article 33 paragraph (3) the 1945 Constitution. The provisions in consideration dictum of letter $a$ of Act No. 26 of 2007 states that:

State area of the Unitary Republic of Indonesia is an archipelago characterized archipelago, either as an integrated container covering land space, sea 
and air, including space in the earth, as well as the resources necessary to improve management efforts wisely, efficiently, effective based on the spatial planning rules so that the quality of the national spatial sustainability can be maintained in order to achieve common prosperity and social justice in accordance with the constitutional basis of the 1945 Constitution of the Republic of Indonesia.

The provisions in the dictum weigh letter $a$ of Act No. 26 of 2007 above, has outlined that the implementation of spatial planning is an activity related to the management of space with wisdom pattern. The pattern of these policies, reflected on the ability to manage space that consist on land, sea and air, including the space in the earth, with the pattern of development is efficient, and effective to improve the welfare of the community, particularly communities to take living in coastal areas the.

The spatial use pattern associated with successful power and effective this debate, because it seems efficient and effective, putting it in a position of empowerment and usefulness of this particular society, not for empower and usability in the community living on the territory of the space. Therefore, in order to avoid misinterpretation of the sentence, the Government is required to provide an understanding of truth, and the truth is concerned is a truth accepted by all parties.

For realize a need achieved by the presence of Act No. 26 of 2007, requires the involvement of the state as an institution which is constitutionally granted right to control all natural wealth contained in it and utilized for the welfare of the people.
Therefore, in the implementation of the use of this space to the maximum, then it must pay attention to the utilization, minimal service standard for spatial arrangement, environmental quality standards and the carrying capacity and environmental carrying capacity. Thus, the determination of the minimum service standards, environmental quality standards and carrying capacity standard and environmental carrying capacity is determined by the Government.

Utilization of coastal areas and the beach is an activity that is very unique, because it affects the entire ecosystem in its surrounding. According to Ambo Tuwo, ${ }^{14}$ that:

"The development of coastal and marine areas that require the cooperation of the parties or stakeholders in the development of coastal and marine areas, the central and local governments, coastal communities, businesses and non-governmental organizations The parties which have an interest in the utilization of natural resources in coastal and marine areas should establish integrated management planning to accommodate all their interests, using the dual-track, top-down or bottom up approaches. The development of coastal area is also requires the integration approach, for the management of coastal and marine areas has a unique territory and diverse resources imply the importance of integrated management of the region".

Referring to the views of Ambo Tuwo above, as a sign that the implementation of the development undertaken in coastal and marine areas, including the implementation of reclamation should be done with the

\footnotetext{
14 Ambo Tuwo. (2011). Pengelolaan Ekowisata Pesisir dan Laut, Pendekatan Ekologi, Sosial-Ekonomi, Kelembagaan, dan Sarana Wilayah. Surabaya: Brilian International, p. 17
} 
integrated approach. Because, in the coastal and marine areas there are some resources between each other intertwined, so that if planning is not done in an integrated manner, then the impact would be dangerous to other ecosystems segmentation. Therefore, the development of coastal and marine areas as well as the reclamation need to consider carefully about the integration approach concerned.

In conducting activities related to the use or utilization of coastal and beach areas, to be wise and prudent. However, the fact remains that, the coastal region has a diversity of marine life, terrestrial biota, and includes in it human activities. Therefore, mistake in plan activities related to utilization of coastal or beach areas including reclamation, which are becoming economic considerations alone, ignoring the interests of ecological and social, it will impact very seriously on all environmental components in around the coastal concerned.

Granting permission for reclamation at this time, because the Government and the local government only considers economically and local revenue. Economic aspect is oriented to income, it is an entrance to the destruction of ecosystems of coastal and beach areas, so what happens is the Government and the local government is only concerned with the development of businesses owned by certain segments of society, and people who do not have the economic well established will be evicted in the name of development and progress of the development in the area.

The activity of development through reclamation, including activities that are related to the use of space as an integral part of the environment. However, the utilization of the space, still refers to the signs as stipulated in Act No. 26 of 2007 on Spatial Planning. To streamline the implementation of the use of space that has been approved by the Government and the local government, then the pattern is done is to control the arrangement of space is concerned. The provisions in Article 7 of Act No. 27 of 2007 states that:

(1) State organized space arrangement to the overall prosperity of the people.

(2) In carrying out the tasks referred to in paragraph (1), the state gives authority to the government and the local government for spatial planning.

(3) The implementation of spatial planning as referred to in paragraph (2) performed by respect the right of any person in accordance with the provisions of the legislation in force.

Referring to the provisions stipulated in Article 7 of Act No. 26 of 2007 above, describes the involvement of state in the spatial plan, which is the command of the Constitution of the Republic of Indonesia and then state delegate to the Government and the local government as an arm of the state. The delegation of authority by state has been given to the local governments concerned, then the Government and local governments must arrange plans for its utilization and use. One of the principal elements of the planning and implementation of spatial planning, is to control the utilization of the space, by setting zoning regulations, licensing and giving special award. The provisions in Article 35 of Act No. 26 of 2007 states that: "control 
the use of space by setting zoning regulations, permits, ${ }^{15}$ incentives and disincentive, as well as the imposition of sanctions."

In line with the detailed spatial plan and spatial plan above, as a requirement in reclaiming the beach, then in the implementation of the reclamation, should not attend to the rights, obligations and role of the community. Society as a subject of legal has rights and duties as well as participation in overseeing the implementation of the reclamation as part of its collective responsibility.

\section{Act No. 32 of 2009 concerning the Protec- tion and Environmental Management}

Protection and environmental management is a concept that wants to do the development of natural resources or the environment, must be interpreted as a balances activity that are environmental, economic and social aspects. These three aspects are to be understood as an integral, not conducted separately, because if done separately, it will affect the integrity of the environment as a whole. Therefore, the implementation of the reclamation as an activity related to some unique ecosystem, because in coastal areas, there are various biota subsystem that mutually between one another, so that the ecosystem of the this coast area, in addition conducted with the approach of the Environmental Impact Assessment (EIA), but also to do with the approach of the Strategic Environmental Assessment (SEA). ${ }^{16}$

15 The provisions in Article 1 point 14 of Act No. 27 of 2007 declared that zoning is a plan to determine the direction of resource use per unit of planning is accompanied by the establishment of structures and patterns of space on the planning area that contains activities that can be done or not as well as activities which can only be done after obtaining permission.

16 See, Article 15 of Act. No 32 of 2009 concerning Environmental Protection and Management.
An approach to the strategic environmental assessment, being raised at this time, because the study started from look (i) the policy; (ii) planning and (iii) program. The third element is the primary determinant of the success of environmental protection and management, especially related to the aspects of policy; it is a first points that determine the direction and planning as well as programs created by the government and local governments on the environment, including reclamation planning. This policy aspect is very important, because often the governments is negligent or ignorant of this aspect, the Government and local authorities assume that, this aspect is an initiative of the Government and local governments to undertake a development activity. The concept of policies related to the strategic environmental assessment and not linked to politics, but related to the legal aspects of state administration, that so-called "law of wisdom" (Freis eremessen).

The linkage between the laws of government policy with environmental assessment lies in the determination of the legal basis of the government issued a policy that was associated with the law and not the political aspect. Therefore, an approach of political aspects in policy making, it is only related to individual ability in determining a development activity in the region, includes in reclamation, and this view is subjective.

The involvement of government and local government in environmental protection and management, as a responsibility as organizer of state and government. As accountability, the Government and local government shall make regulations relating to 
the duties and responsibilities, as a basis in carrying out its duties and responsibilities. One of the duties and responsibilities is government and local government related to the environmental protection and management.

The concept of Strategic Environmental Assessment (SEA), is now as a new concept and it has been practiced in some European countries, and it appears that Indonesia has adopted in Act No. 32 of 2009 concerning the Environmental Protection and Management. The concept of SEA by some Western writers, including Chaker et al, suggests the existence of four concepts that become a reference of SEA, namely: ${ }^{17}$

1. SEA is based on the concept of environmental impact studies; SEA conducted under the rules and procedural of EIA study. In this case, the implementations of SEA resemble EIA, in terms of both procedural and methodology used. SEA applied to Policies, Plans, and/or the Program (PPP) has been formulated (tool for assessing for decisions). Also, known as the SEA study pattern that oriented to EIA concept, which focus on environmental impact assessment is expected to occur as a result of PPP (Environmental Impact Assessment Driven).

2. An integrated approach: SEA being part of the planning process and the formulation of PPP. This approach in methodology focuses on the utilization of criteria and sustainable development indicator as a measure of environmental interests that must be con-

17 Chay Asdak. (2014). Kajian Lingkungan Hidup Strategis, Jalan Menuju Pembangunan Berkelanjutan. Yogyakarta: Gadjah Mada Univesiry Press, pg. 70-71. sidered in the formulation of PPP (tool for orienting decisions). In this case, the pattern of SEA study oriented to the sustainable development concept (sustainability-driven).

3. Dual track approach; processes and procedures for implementing the SEA concurrent, but separate from the process of planning and formulation of PPP. The study results two documents separately, one PPP documents, and other is environmental report.

4. Decision-centered approach: planning and decision-making processes determine the type and direction of SEA frameworks. In other words, the SEA study conducted by adapting to the process of planning and decision making. This is to ensure that the process of implementation of SEA can adapt and conform to the requirements of strategic decision making process in the development plan (e.g Region Spatial Plan or Middle Term Development Plan).

Referring to the views of Chaker above, gives an overview of the concepts associated with the implementation of sustainable development, by focusing four concepts that guide in designing the concept of sustainable development. Therefore, the concept of SEA has developed in European countries, have started to leave the concept of EIA gradually. Therefore, although the SEA study has similarities with the EIA, but the difference lies in the initial study, which examines the first concerns policies, new plans and final program, and the third patterns are able to see the weak side is the 
case today in policy studies. In addition, the resulted documents by SEA study have two separate documents, while the EIA study is only unity of environmental documents.

\section{Act No. 23 of 2014 concerning Local Go- vernment}

Indonesia as an archipelago country has about 31 provincial and 235 districts and 120 cities. It put the provincial and district/city, as the area is given the autonomy to administer and manage their own region. The existence of legislation regulating the region has been amended several times, and any changes in it was also a change of clauses deemed not responsive to the development of an issue. Certain changes were so fundamental that relates to Act No. 23 of 2014, related to government affairs, laid down in Article 9 of Act No. 23 of 2014 states that:

(1) The affairs of government composed of absolute governmental affairs, concurrent government affairs, and general government affairs;

(2) The absolute government affairs referred to in paragraph (1) is a fully government affairs under the authority of the Central Government;

(3) The concurrent government affairs referred to in paragraph (1) is a government affairs are shared between the central government and the province and districts/cities;

(4) The concurrent government affairs are delegated to the local as a basis for local autonomy;

(5) The general government affairs as referred to in (1) are government affairs under the authority of the President as head of government.

In line with the provisions set forth in Article 9 of Act No. 23 of 2014 above, Act No. 23 of 2014 also establishes the authority of the province in the sea and characterized by islands, which is regulated in Article 27 of Act No. 23 of 2014 states that:

(1) Provinces given the authority to manage the natural resources in the sea in its region;

(2) The authority of the provinces to manage natural resources in the sea as referred to in paragraph (1) includes: a. exploration, exploitation, conservation, and management of marine wealth beyond oil and gas; $b$. administrative arrangements; c. spatial arrangement; $d$. participate in maintaining the security of the sea; and e. participate in maintaining state sovereignty;

(3) The authority of the provinces to manage natural resources in the sea as referred to in paragraph (1) the most distant (twelve miles) 12 nautical miles from the coastline to the offshore and/ or towards the archipelagic waters;

(4) The provisions referred to in paragraph (3) and (4) do not apply to fish catching by fishermen for a province that is characterized by islands.

Referring to the provisions set forth in Article 27 of Act No. 23 of 2014 above, then the provinces are given the authority to manage the natural resources in the sea in its region, and this includes a wealth of natural resources in the sea, the beach or coast is a part from the sea is concerned. In addition, the natural wealth in the sea such coast, including coast spatial of provincial has the authority to carry out exploration, exploitation, and the spatial arrangement of the coastal areas.

Granting authority to local governments to manage natural resources in the sea, be a trigger for several local governments to do reclamation in its region. The development of economic zones, the lack of area is the main reason by the local government for 
reclaiming beaches or islands. One example, the regional administration of Jakarta by the Governor of Basuki Tjahaya Purnama (Ahok) issued a permit for reclamation of beaches in around North Jakarta, Governor Ahok issues a permit for reclamation, on the one hand there has been no local regulation on new spatial and zoning, because while in the discussion.

\section{Legal Analysis of Reclamation}

Reclamation activities began emerge, when the revealed of reclamation case and the develop of some islands in the Bay of Jakarta, which dragged Chairman of Commission II of Regional Parliament DKI languishing in the prison, for bribery occurs in the discussion of the Spatial Zoning draft and the coastal area zoning. ${ }^{18}$ Therefore, the problem of reclamation in Indonesia must be made from the analysis of Islamic- and positive laws, and both the analysis which is the most useful of dangerous.

\section{Analysis from the Perspective of Islamic Law}

Islamic law derived from the holy book Qur'an and its norm directly from God Almighty, norms contained in the Holy Book of the Qur'an, is command that was sent to all creatures, including humans. Islamic law considers the universe as a law that wants that people always run the virtues and values that are useful in it, the surrounding natural environment and other human beings. Islamic law that originates in the Quran, to be

18 Tempo Magazine. "Reklamasi Tujuh Keliling, KPK Menelusuri Keterlibatan Staf DKI dalam Kasus Suap Teluk Jakarta, Ahok Terseret", 11-17 April 2016 Edition, page. 16 human as caliph or representative of God on earth, and one of his duties as the caliph is to keep the universe is not undermined and keep its balance by preserving the environment.

Related to reclamation activities, the Islam considers such activities may be carried out if it has more benefit for the benefit of mankind, and not vice versa. Because, what happens during this time, reclamation displacing poor people (fishermen) from the place of residence, removing their livelihood, eliminate customary which they have been doing, and then reclamation benefit a few people, the "entrepreneurs" or owners of capital, Allah has warned in the holy book Qur'an, Surah al-Baqarah (11) and (12) Allah says:

"And when it is said to them, do not make mischief in the land, they say: We are but peace-makers. Now surely they themselves are the mischief makers, but they do not perceive."

Meaning contained in (Q.S. AlBaqarah: 11-12) suggests that the activities being carried out by humans in the form of beach reclamation activities, according to the human mind does mischief, but peace maker by establishing centers of economic activity, but on the other hand has destroyed the environment by moving people from their place, and pile of sea in which there are various kinds of marine life that have the right to live with humans.

The reclamation, including the activities included in the destruction of nature, because the activities contains in it, because of greed lust, not because they have a lofty goal, namely to maintain small community. Reclamation activities to move people as- 
sumed that to elevate fisherman human dignity, something that is biased, because the entrepreneur who has conducted reclamation has collaborated with certain persons in the local representative, the Government and employers. This collaboration, as a result of the Indonesian nation has been changing civilization of the mutual cooperation, mutual love and respect for each other has been turned into a pragmatic materialism civilization. This pragmatic materialism civilization is the western civilization that the human worship the individualism, which measure the success seen from the ability to collect the treasures as much as possible, without regard to the people who were in the vicinity.

Hobby activities of reclamation is increasingly widespread in several regions in Indonesia, has produced a new civilization of Indonesia which was carried by certain people, who already have the capital very much and supported by the collaboration between the employers and government, then there is leaving a conflict with the people who have settled in the coastal areas. ${ }^{19}$

Reclamation activities of coast as a new civilization for the nation of Indonesia, has implications profound for Indonesia, because we have lost our national identity built by the founder of the Indonesian nation with the permission of God Almighty, one of which is economic Pancasila that carries cooperative. Cooperative as the Indonesia nation's economic pillar has been replaced

19 A case of reclamation in Jakarta leaves the problem because there is no foundation in the form of local regulation, in Genoa Bali, people demonstrate for devastating the mangroves, in Banten the fishing's communities protested, because they have lost their livelihoods, in Palu terminated by the Governor for a while, because it is not accordance with the legislation in force. by a pillar of economic capital, liberal, and what happens is this nation has been dragged away, so have forgotten the dignity and status and mortgaged with the dignity of other nations.

Western civilization is a civilization that separates between human activities with the unity of God, and to assume that western civilization is the civilization the greatest compared to other civilization in the world. Western civilization prefers to the intellectual ability and ignores the ability of conscience, western civilization is a civilization that considers the universe is an object that can be controlled and conquered for their interest, and a benchmark for measuring welfare. Western civilizations respect for themselves than others, and assume that they have a higher degree than others.

While Islamic become a nature as created by Allah, which was created for the benefit of mankind, and given to man as caliph, and man as caliph required maintaining and taking good care. Humans are given the right to manage and exploit nature, the condition should not be destructive and excessive, and allowed natural maintained by humans, but for the sake of the welfare of the human being as a whole and not for the interests of certain people.

\section{Analysis from the Perspective of Positive Law}

Positive law is theoretically as legislation made by the Government and the Parliament, which its validity for certain country. The entire legislation made by the Government with Parliament related to the regulation of natural resources, namely Act No. 27 of 
2009 on Coastal Areas and Small Islands, Act No. 26 of 2006 on Spatial Planning, Act No. 32 of 2009 on the Environmental Protection and Management, and Act No. 23 of 2014 on Local Government, and the Presidential Decree No. 122 of 2012 on Reclamation in Coastal Areas and Small Islands, and No. 17/PERMEN-KP/2013 on Licensing for Reclamation in Coastal Areas and Small Islands and Regulation of the Minister of Public Works No. 40 / PRT / 2007 on Guidelines of Spatial Planning of Reclamation Area. Entire legislation as a basis in implementing coast reclamation in Indonesia.

Refer to all the provisions contained in the entire legislation above, normative almost nothing is missed, because the whole has determined to undertake the reclamation for development. Reclamation at this time has experienced a long debate between the pros and cons, the pros say that the implementation of reclamation to create jobs and take advantage of the sea for the sake of development, because the land has been filled for accommodate population. Reclamation which entered into an era of economic competition involving big employers with other, and the victim is a small fishing community, because they get does not have the capability to fight government and entrepreneurs to collaborate. A simple question, what role is given by all laws and regulations related to the implementation of reclamation concerned.

Theoretically and using positive law in Indonesia, which has always relied on to resolve the public problem, one of them is reclamation of legislation in question has not been maximized. Therefore, the positive law in which includes chapters as norms governing human, public not demonstrate efficacy, because the articles are just a language of game. Satjipto Rahardjo ${ }^{20}$ said that the law supremacy that has been echoed is only sign without meaning. Legal texts only language of the game that tends to deceive and disappoint. On the other hand, Chambliss \& Seid$\operatorname{man}^{21}$ said that the law is executed everyday is a myth and the myth that every day be proven lies.

Begins with a view of Satjipto Rahardjo and Chambliss \& Seidman above, implies the truth, in reality, legislation related to the implementation of reclamation becomes a fact, that the positive law was only language of game by members of Parliament and Government when discussing the presence legislation. An example implementation of reclamation in North Jakarta that leave a case to legislators Muhammada Sanusi, this indicate that there are buying and selling the articles ordered by certain employers. Central Sulawesi in Palu, beach reclamation of Talise case also suspended construction by the Governor, because it does not meet the requirements requested one of which is the analysis of the environmental impact has not been there, and a feasibility study and environmental permits. With the two cases in question related to the implementation of reclamation, it is evident what is proposed by Satjipto Rahardjo and Chamblis \& Seidman that the law is full of lies and myths, so that the lies have been born along with a

$20 \quad$ Satijpto Rahardjo. (2009). Penegakan Hukum Suatu Tinjauan Sosiologis. Yogyakarta: Penerbit Genta Publishing, p. x

21 William J. Chambliss \& Robert B. Seidman. (1971). Law, Order and Power. Mass Addison-Estley, p. 3 
discussion that did in the parliament and local representative.

Reclamation conducted by the Government and the local government through the granting of permission to the private entrepreneurs to implement, on the one hand normative properly because it has a legal basis to do so. However, on the other hand the reclamation raises 3 (three) conflict, namely (i) between the Government and local government and communities living around the coast (the fishing community); (ii) people with employers who reclaiming and (iii) the Government and local governments with employers who do reclamation.

With conflict of interest, it can be concluded that the legislation made by the Government and local governments to regulate the implementation of reclamation is unsuccessful. The failure, because the Indonesian people looked at the legislation is a living thing that is able to regulate the human being as a living thing, whereas legislation inanimate objects, which will move when driven by humans. Therefore, it is said by Satjipto Rahardjo 22 that: "a progressive law was actually simple, doing exemption, both in ways of thinking and acting law, so as to allow it to flow just completed his legal duty to serve the mankind and humanity".

It's illustrates the Indonesian nation is too idolize positive law (legislation) as the commander who is able to complete the entire Indonesian nation's problems, but it has not been able to finish. Therefore, what is needed in managing the positive law in the future, so being able to solve problems that

22 Satjipto Rahardjo. (2010). Penegakan Hukum Progresif. Jakarta: Kompas, p. 69 arise in the state and society. ${ }^{23}$

In line with the views of progressive law by Rahardjo above, then in principle the positive law necessary to break the validity this time, not just to manage human, but more toward humanizing, because if not humanize humans, then the positive law will lose its harmony. Related this, according to Farida Patittingi ${ }^{24}$ necessary balance and harmony between positive law and the law in the society as a guide in taking legal action. To that end, referring to the legal system adopted in Indonesia, the presence of positive law is still needed to provide legal certainty, but the incarnation should be in the catchment of the natural law that blend in positive law, so realize a justice.

Associated with the implementation of reclamation occurred in several regions in Indonesia, which is currently experiencing a fundamental conflict, is an issue that should be viewed from the perspective of positive law alone. However, necessary in the perspective of humanity, because human beings lawful than vice versa. Indonesian, represented by the Government and local governments has an obligation to create legislation that can provide a sense of security, a sense of well-being, not vice versa. Therefore, if the Government and local government not implement the law properly, which is always enforcing the legislation unanimously, and then it is not impossible that this nation will have a very serious problem. Note the

23 Hamdan Zoelva. (2015). "Prospek Negara Hukum Indonesia: Gagasan dan Realita. Hasanuddin Law Review, 1(2), 178-193. doi: http://dx.doi.org/10.20956/ halrev.v1n2.78

24 Farida Patittingi. (2009). Pengaturan Penguasaan Tanah Pulau-Pulau Kecil di Indonesia. Yogyakarta: Penerbit Lanorka, pg. 106-107. 
problems small communities, may not show the Government and local authorities pleaded provides protection to certain circles in the country, by moving the officers in the country to fight the public, and the public will never be against the state or the government or the local government, if the Government and local government shows his sense of justice.

\section{CONCLUSION}

Coast reclamation viewed from the perspective of Islamic law, giving a warning that the universe is created by God for all His creatures on the earth. God as the absolute owner of the earth and all contents in it were ordered to be managed and utilized for the benefit of all mankind, with annotate not damage and should not be excessive in the management and utilization. Therefore, the reclamation if it is done for the benefit of the mankind, not only to meet the needs of a handful of people, then it is not justified by God as the sole owner of the earth and all contents in it.

The reclamation viewed from the perspective of positive law, can be done for some requirement that must be fulfilled by the employer or the person who will carry out reclamation concerned. However, despite otherwise have had laws that govern it, but it happened a triangular conflict, due to the interest from each other. The interests of the Government and local governments related to local revenue, and the interests of employers related to benefits to be gained if the reclamation for the construction of facilities and infrastructure, while the people who live around the coast had the very importantly, because the place to make a living and livelihood. Reclamation that occurred in some areas due to the collaboration between the employers, the government and the government, and collaboration that causes employer dare to do reclamation, even though not yet meet the requirements specified in the legislation.

\section{BIBLIOGRAPHY}

Abdoel Raoef Soehoed. (2004). Reklamasi Laut Dangkal, Canal Estate Pantai Mutiara Pluit, Perekayasaan dan Pelaksanaan Reklamasi bagi Proyek Pantai Mutiara di Pluit Jakarta. Jakarta: Djambatan.

Abu Fatah Al-Adnani. (2008). Global Warming, Sebuah Isyarat Dekatnya Akhir Zaman dan Kehancuran Dunia. Surakarta: Granada Mediatama.

Ambo Tuwo. (2011). Pengelolaan Ekowisata Pesisir dan Laut, Pendekatan Ekologi, Sosial-Ekonomi, Kelembagaan, dan Sarana Wilayah. Surabaya: Brilian International.

Chay Asdak. (2014). Kajian Lingkungan Hidup Strategis, Jalan Menuju Pembangunan Berkelanjutan. Yogyakarta: Gadjah Mada Univesiry Press.

Emil Salim. (2010). Ratusan Bangsa Merusak Satu Bumi. Jakarta: Kompas Penerbit Buku.

Fachruddin Mangunjaya et al., (2007). Menanam Sebelum Kiamat, Islam, Ekolgi, dan Gerakan Lingkungan Hidup. Conservation International Indonesia Islamic College for Advanced Studies (ICAS). Jakarta: Yayasan Obor Indonesia. 
Farida Patittingi. (2009). Pengaturan Penguasaan Tanah Pulau-Pulau Kecil di Indonesia. Yogyakarta: Penerbit Lanorka.

H.M. Talhah \& Achmad Mufid. (2008). Fiqih Ekologi, Menjaga Bumi Memahami Makna Kitab Suci. Yogyakarta: Total Media.

Hamdan Zoelva. (2015). "Prospek Negara Hukum Indonesia: Gagasan dan Realita. Hasanuddin Law Review, 1(2), 178193. doi: http://dx.doi.org/10.20956/ halrev.v1n2.78

Mukhtasor. (2007). Pencemaran Pesisir dan Laut. Jakarta: PT. Pradnya Paramita.

Peter Machmud Marzuki. (2011). Pene- litian Hukum. Jakarta: Pranada Media Group.

Satijpto Rahardjo. (2009). Penegakan Hukum Suatu Tinjauan Sosiologis. Yogyakarta: Penerbit Genta Publishing.

Satjipto Rahardjo. (2010). Penegakan Hukum Progresif. Jakarta: Kompas.

Tempo Magazine. "Reklamasi Tujuh Keliling, KPK Menelusuri Keterlibatan Staf DKI dalam Kasus Suap Teluk Jakarta, Ahok Terseret", 11-17 April 2016 Edition.

William J. Chambliss \& Robert B. Seidman. (1971). Law, Order and Power. Mass Addison-Estley. 